\title{
Entrepreneurship Development in Management of Intra School Student Organizations in SMA/ SMK Level in the East Indonesian Province
}

\author{
Agus Subagyo, Agustina Setiawan, Titin Rohayatin, Dadan Kurnia, ling Nurdin, \\ Widuri Wulandaria), and Siti Munawaroh
}

Fakultas IImu Sosial dan IImu Politik, Universitas Jenderal Achmad Yani, Indonesia

a)Corresponding Author: widuri.wulandari@lecture.unjani.ac.id

\begin{abstract}
Understanding of entrepreneurship and organizational management, especially at the OSIS and MPK levels, is still deficient. With a lack of understanding related to entrepreneurship and organizational management at the school level, lecturers at the Faculty of Social and Political Sciences (FISIP) Unjani organize Education and Training for OSIS at the SMA/SMK in the Eastern Province of Indonesia. The method used in this community service is to provide material related to entrepreneurship development and organizational management, and creativity competitions for OSIS and MPK members between schools. Community service related to entrepreneurship development in the management of Intra-School Student Organizations runs smoothly and in accordance with the desired expectations. Students participate actively in every series of activities held. In addition to participating in the Webinar as the pinnacle of community service, students also participate in the preparation of school creative business proposals, poster making competitions, and Share Content competitions. Thus, community service activities carried out by FISIP Unjani make a positive contribution in providing new understanding and thoughts as well as ideas, ideas, creative innovations that can be applied and implemented in organizations and in the school environment where they study. and form an entrepreneurial spirit, namely a leader who has an entrepreneurial spirit.
\end{abstract}

Keywords: Entrepreneurship Development, Organization, Community Service

\section{INTRODUCTION}

In order to support and realize the creation of future Indonesian leaders who have a strong leadership spirit, have a high sense of discipline and broad insight, and have a great sense of responsibility towards an organization including the Intra-School Student Organization (OSIS) and the Class Representative Council (MPK). Therefore, it is necessary to provide early training, one of which is through training in the basics of organization and entrepreneurship development. OSIS is a legitimate student organization in schools. OSIS is a group of interpersonal cooperation held to achieve common goals. As an organization, OSIS was formed in an effort to achieve student development. That OSIS is the only forum for student activities in schools along with other coaching pathways to support the achievement of student development. To realize its function as a forum, OSIS must always work together with other channels in conducting leadership training, extracurricular activities, and insight into wiyatamandala. Without cooperating with others, the Student Council as a forum will not function properly.

OSIS is one of the pathways for student development, and is a system that functions as a place for group life of students to work together to achieve common goals. Therefore, this is the basis for holding training on the basics of leadership, basic discipline, organizational basics and entrepreneurship development for OSIS management and MPK members conducted by the Organizing Committee for FISIP Unjani training activities.

According to Hafsah in (Enny Widayati, Haswan Yunaz, Tagor Rambe, B.Wishman Siregar, Achmad Fauzi, 2019) development is an effort made by the government, the business world, 
and the community through the provision of guidance and reinforcement assistance to grow and improve the ability of small businesses to become strong and independent businesses.

Entrepreneurial activities have a dynamic process in order to create something that is accompanied by models, resources, time, and risks that may occur. Entrepreneurship is a process in identifying, developing and realizing the vision and mission of the business.

The objectives of entrepreneurship education according to (Daryanto, 2012) are as follows:

a) Entrepreneurship has a goal to form a body of knowledge, not just studying concepts and theories

b) Entrepreneurship consists of venture statd-up and venture growth, which is about starting a business and managing business growth

c) Entrepreneurship is related to the ability to produce something new

d) Entrepreneurship learns to recognize revenue management

According to (Christian Frijs, Thomas Paulsson, 2002) entrepreneurship is a functional entrepreneur and includes coordination, innovation, bearing, uncertainty, capital provision, decision making, ownership, and resource allocation. These functional roles include taking risk (risk seeking), innovation (innovativeness), and seeking opportunities (opportunity seeking).

Those who become entrepreneurs are people who recognize potential and learn to develop it to seize opportunities and organize businesses in realizing their goals. Entrepreneurship is a creative and innovative ability, keen to see opportunities and always open to any positive input and changes that can bring the business to continue to grow and have value. One of the drivers of innovation besides change and the need to adapt is the awareness of the gap between what is and what should be, and between what the community wants and what has been offered or done by the government, the private sector and non-governmental organizations (NGOs) (Saragih, 2017).

Meanwhile, (Sander and Roy Thurik, 1999) define entrepreneurship as the real ability and willingness of individuals who come from themselves, in teams inside and outside existing organizations, to find and create new economic opportunities (new products, new production methods). , new organizational schemes, and new market-goods combinations), and to introduce their ideas to the market, in the face of uncertainty and other obstacles, by making decisions about the location, form and use of resources. Meanwhile, McClelland in (Suryana, 2001) states that entrepreneurship is determined by achievement motives (achievement), optimism (optimism), and value attitudes, and entrepreneurial status (entrepreneurial status) and success.

The principles of entrepreneurship according to Khafidhul Ulum in (Sudaryono, 2011), are: Passion, Independent, Marketing sensitivity, Creative and innovative, Calculate risk taker Persistent, High etchical standard. According to (Bygrave, W., 2009) there are 10 entrepreneurial characteristics known as 10 D, namely: Dream, Decisiveness, Doers, Determination, Dedication, Devotion, Details, Destiny, Dollars, Distribute.

Entrepreneurial spirit can be developed for school students from elementary, middle to advanced levels, colleges and various courses. Students can start creating and innovating by targeting market share starting from their own school and then developing wider. The support of resources owned by an area needs to get support in the form of developing an entrepreneurial spirit through the process of extracting creativity and innovation which will make students a young generation with independent personalities and can even become economic drivers in the future. This is needed because not all high school graduates will enter higher education considering the capacity of higher education or because of the choice of the graduates themselves who choose to work or become entrepreneurs. Someone who is an entrepreneur does not close the opportunity to obtain a higher education because with entrepreneurship someone can finance his own education and can even open new markets from his educational environment (Ninin Non Ayu Salmah, Nisa'Ulul Mafra, 2019). 


\section{METHOD}

The method used in the successful implementation of community service with the title "Bhakti Negeri Unjani through Entrepreneurship Development in Management of Intra-School Student Organizations at the High School/Vocational Level in the Eastern Province of Indonesia," FISIP Unjani uses several approaches, such as:

1. Preparation Stage; in the preparation stage, a series of activities were carried out such as the OSIS creativity competition and inter-school MPK members guided by the FISIP Unjani organizing committee. The competitions were held such as competitions for the preparation of school creative businesses, poster making competitions, and content sharing competitions. The preparation stage will be held from April 2 to June 30, 2021, including the assessment of the race.

2. Implementation Phase; This implementation stage is the culmination of community service activities carried out by FISIP Unjani, which will be held on July 1, 2021 through Webinar activities. The implementation of this Webinar is Hybrid, namely offline and online. The offline implementation is intended for all lecturers as the implementing team for Community Service activities along with leaders in the FISIP Unjani environment and leaders at the University level. The location for the offline implementation is at the General TNI Mulyono Building, Hall 4th floor, FISIP Unjani. Meanwhile, the online implementation is intended for webinar participants as OSIS and MPK administrators in Eastern Indonesia and for presenters.

The speakers in this community service activity are:

a. Entrepreneurship Development in Organizations, by Dr. H. Sandiaga Salahudin Uno, B.B.A., M.B.A (Minister of Tourism and Creative Economy)

b. Organizational Management, by Prof. Muchlis Hamdi, MPA., Ph.D (Special Staff of the Minister of Home Affairs for Government Affairs)

3. Evaluation Phase; At this stage of activity, the implementing team for community service activities evaluates all activities from the preparation, implementation and preparation of activity reports.

\section{RESULTS}

The results of the implementation of Community Service Activities with the title "Bhakti Negeri Unjani Through the Basics of Leadership, Discipline and Entrepreneurship Development in the Management of Intra-School Student Organizations at the High School/Vocational Level in the Eastern Province of Indonesia" are as follows:

1. Activity Time

a. Preparation process. The whole process of Community Service activities is carried out for 6 full months, starting from making proposals, sending information about Unjani State Service activities, announcements of competition participation, announcements of types of competitions to webinars.

b. Information is sent via email to each school, IG of each school, some via telephone, chat via WA, IG for guidance and counseling teachers, and for the Greater Bandung area, Roadshows were conducted to several schools.

c. The process of making the type of competition will be informed from April 5 to June 20, 2021.

d. Assessment by the jury on the type of competition sent by the participants from June 21 to June 30, 2021

e. The Webinar activity will be held on Thursday, July 1, 2020 from 07.30 to 17.00 WIB.

\section{Nature and Place of Activity}

a. This PPM activity is carried out in a hybrid manner, namely online and offline.

b. Activities that are online for all presenters and all webinar participants, namely OSIS and MPK management students throughout Indonesia and take place at the residences of each presenter and each participant, 
c. Activities that are offline for all implementing teams for Community Service activities and leaders at the Faculty level (FISIP) and University level leaders (Unjani). The offline activity was held in the 4th Floor Hall of the TNI Mulyono Building, FISIP Unjani, which is located at Terusan Jenderal Sudirman Cimahi street.

\section{Activity participants}

a. The participants of the Webinar were 860 people who were OSIS and MPK administrators spread throughout Eastern Indonesia. The number of participants is obtained from participants who fill in the attendance in the Google Form.

b. The number of participants, for example, from Eastern Indonesia, for example, is from YPKPM Christian High School Ambon, South MOLO 1 SMUN, NTT, 3 MATARAM SMAN, K DIAN Halmahera High School.

1. Speaker

The speakers in this Webinar are as follows:

a. Prof. Muchlis Hamdi, MPA., Ph.D (Special staff of the Minister of Home Affairs for Government Affairs)

b. Dr. H. Sandiaga Salahudin Uno, B.B.A., M.B.A (Minister of Tourism and Creative Economy)

c. FISIP Unjani Lecturer Team

2. Activity Material

The material in the Webinar activity is as follows:

a. Organizational Management

b. Entrepreneurship Development in Organizations

c. Coaching or tutorials and Assistance in the Process of Making Activity Proposals, Entrepreneurship Development Activity Reports related to one of the functions of the Student Council

3. Stages of the Webinar. In this stage is the stage of providing material which is divided into:

a. Organizational Management

b. Entrepreneurship Development in Organizations

c. Coaching or tutorials and Assistance in the Process of Making Activity Proposals, Reports on entrepreneurship development activities related to one of the functions of the Student Council, starting from tips and strategies for making proposals, making reports and procedures for developing entrepreneurship in organizations

4. Several parties involved in this PPM activity

a. Minister of Tourism and Creative Economy

b. Special Staff of the Minister of Home Affairs for Government Affairs

c. Leader of University

d. Faculty Leader

e. Representatives of BK teachers throughout Indonesia

f. Representatives of the OSIS Management at the SMA/SMK/Equivalent level throughout Indonesia

g. Representatives of MPK Management for SMA/SMK/Equivalent levels throughout Indonesia

h. All Lecturers in the student environment

i. Representative of BEM FISIP

j. FISIP student representatives

\section{DISCUSSION}

In an increasingly advanced era, education in Indonesia is required to play a role in producing quality human resources (HR). Quality human resources are not only following the development of science and technology that is increasingly rapidly but also able to develop themselves in an effort to adapt to the times, such as understanding entrepreneurship and organizational management from an early age. However, the purpose of education is not only 
obtained through formal learning in the classroom, but is obtained through the involvement of students in an organization. Organizational activities are activities to assist the development of students according to their needs, interests, talents and potential through activities held in schools.

Indonesia in 2020-2035 will experience a demographic bonus (30\% dominance of productive age 15-34 years) where the productive age population is more than the nonproductive age, and is predicted to experience a peak demographic bonus in 2030. The positive impacts include economic growth, improving opportunities in producing superior human resources so that they can be competitive, increasing people's living standards, opening new job opportunities, as well as advancing and developing local industries. However, in addition to positive impacts there are also negative impacts such as an increase in the number of unemployed, if a large population is not followed by a good quality of environmental awareness, it will result in the degradation of environmental damage, the workforce will be dominated by foreign workers if the population does not have good skills, the burden of the state is getting heavier, and the poverty rate is high.

In order to maximize the potential of young people in facing the demographic bonus, namely the 3E (Education, Employement, and Engagement). Education (education) by improving the quality of education to improve hard skills and soft skills. Employment (jobs) is to create jobs to absorb abundant labor. Engagement (participation) in this case young people actively participate in political, social, and economic activities. The demographic bonus can be likened to a double-edged sword, namely one side is a blessing if it can be used properly, but it can be a disaster if the quality of Indonesian people is not prepared properly.

The linkage of entrepreneurship development education and training activities in OSIS is expected to improve individual performance capabilities and the quality of human resources as system implementers in organizations, especially Intra-School Student Organizations (OSIS) and be able to form self-esteem as a prospective leader to form strong, disciplined individuals. , and never give up mentally, physically, and spiritually from every individual in the organization and has a spirit of interpartnership. It can be believed that this activity can affect the quality of performance in the process of implementing management or organizational governance that is better and more accountable. Entrepreneurship is a discipline that studies the values, abilities, and behavior of a person in facing life's challenges to obtain opportunities with various risks that they may face (Suryana, 2001).

Thus, it is important to be able to provide education to the younger generation, in this case the Student Council in entrepreneurship development. Community service activities carried out in the form of coaching or tutorials and Assistance in the Process of Making Activity Proposals, Reports on entrepreneurship development activities related to one of the functions of the Student Council, starting from tips and strategies for making proposals, making reports and procedures for developing entrepreneurship in organizations. In this case, the materials related to entrepreneurship provided consist of: tips and strategies for preparing entrepreneurship proposals, tips and strategies for forming school business units, and marketing strategies for school business units.

In addition, students are also trained to be able to work in groups or independently and have a sense of responsibility for the tasks given to each individual as the executor of an organization. other to support the achievement of student development, through this activity is expected to be able to provide a solution to a problem that occurs in OSIS and MPK. The implementation of the organizational management process at the SMA and SMK levels begins with quality human resources. The quality of Human Resources is supported by the performance of each individual as a system implementer in a performance organization, one of which can be done through education and training in entrepreneurship development and organizational management.

Education and training in the context of developing entrepreneurship in the management of Intra-School Student Organizations is reflected in the quality of the students in terms of preparing school creative business proposals, making posters, and sharing content via social 
media. Community service carried out by FISIP Unjani in addition to holding competitions which were participated by students, there was also material from resource persons, who provided material related to Entrepreneurship and Organizational Management. There are 3 (three) main aspects in realizing an organization that is fast and accurate in serving, namely: (1) Regulation, there is a clear arrangement as a legal basis or umbrella/rule of the game such as the Standard Operating Procedure (SOP), which is clear and agreed upon. together. (2) Human Resources $(\mathrm{HR})$, the availability of reliable, adaptive, innovative, and quality human resources in supporting the implementation of organizational goals. (3) Institutional, appropriate organizational structure, function and size supported by clear management and able to respond to developments in the internal and external environment.

In addition, the material provided describes how the younger generation can create business opportunities during a pandemic like what is happening right now. New job opportunities that can be formed such as digital-based businesses, creative economy industries, and freelancer opportunities. Related to digital-based business, it can be a potential business when viewed from internet users, social media users that can be utilized by entrepreneurs, especially during this pandemic. According to the Minister of Tourism and Creative Economy, there are 3 (three) things in entrepreneurship, namely Gercep (Fast Movement), Geber (Joint Movement), and Gaspol (Working on All Potential Fields).

Thus, the implementation of community service activities in the form of Education and Training organized by the Faculty of Social and Political Sciences, Jenderal Achmad Yani University with OSIS and MPK management participants spread throughout Eastern Indonesia, focuses on several stages of activities carried out such as competitions and competitions. as well as webinars related to entrepreneurship and also organizational management, the hope is that after being given coaching and assistance regarding the Making of Activity Proposals, Entrepreneurship Development Activity Reports which is one of the functions of the Student Council, they are able to apply it in school.

\section{CONCLUSIONS AND RECOMMENDATIONS}

Community service activities carried out by FISIP Unjani made a positive contribution to efforts to increase knowledge, understanding and mastery of entrepreneurship development and organizational management for high school/vocational high school students in Eastern Indonesia. Provide new understanding and thinking as well as creative ideas, ideas, innovations that can be applied and implemented in organizations and in the school environment where they learn. Prepare and shape the entrepreneurial spirit, namely leaders who have an entrepreneurial spirit.

\section{ACKNOWLEDGMENTS}

This community service is part of Unjani's internal grant, whose funding comes from the LPPM (Institute for Research and Community Service). Therefore, the FISIP Unjani lecturer team would like to thank LPPM Unjani for the trust and funding provided to support the implementation of Community Service.

\section{REFERENCES}

Bygrave, W., \& Z. A. (2009). The Portable MBA in Entreprenurship. New Jersey. John Wiley and Sons, Inc.

Christian Frijs, Thomas Paulsson, dan C. K. (2002). Entrepreneurship and Economic Wrowth: a critical review of empirical and theoretical research. Intitutet for tillvaxtpolitiska studie.

Daryanto. (2012). Pendidikan Kewirausahaan. Gaya Media.

Enny Widayati, Haswan Yunaz, Tagor Rambe, B.Wishman Siregar, Achmad Fauzi, R. (2019). PENGEMBANGAN KEWIRAUSAHAAN DENGAN MENCIPTAKAN WIRAUSAHA BARU DAN MANDIRI. Jurnal IImiah Manajemen Bisnis Dan Inovasi Universitas Sam Ratulangi, 6(2), 98105. 
Ninin Non Ayu Salmah, Nisa'Ulul Mafra, R. D. (2019). PENGEMBANGAN JIWA KEWIRAUSAHAAN MELALUI KREATIVITAS DAN INOVASI SISWA SMAN 1 INDRALAYA SELATAN. J-Abdipamas (Jurnal Pengabdian Kepada Masyarakat, 3(2).

Sander and Roy Thurik. (1999). Linking Entrepreneurship and Economic Growth. Small Business Economics.

Saragih, R. (2017). MEMBANGUN USAHA KREATIF, INOVATIF DAN BERMANFAAT MELALUI PENERAPAN KEWIRAUSAHAAN SOSIAL. Jurnal Kewiraushaan, 3(2), 26-34.

Sudaryono. (2011). Kewirausahaan. Andi.

Suryana. (2001). Kewirausahaan. Salemba Empat. 


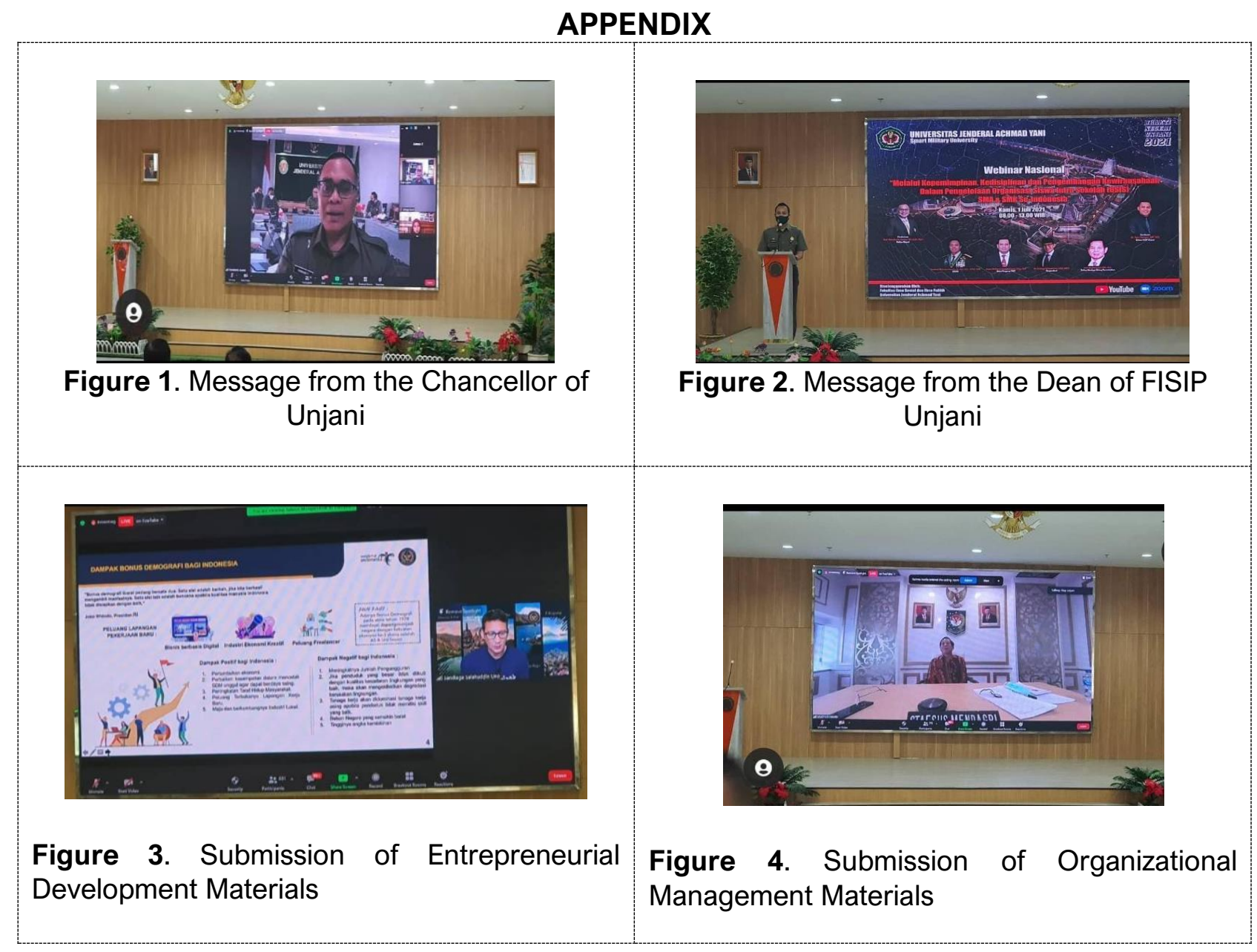

